\title{
INFLUENCE OF CARBON AND NITROGEN IMPURITIES ON THE CORROSION OF STRUCTURAL MATERIALS IN A FLOWING LITHIUM ENVIRONMENT*
}

O. K. Chopra and A. B. Hull

\author{
Materials and Components Technology Division \\ Argonne National Laboratory \\ Argonne, Illinois 60439
}

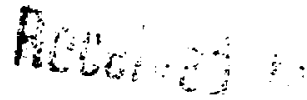

FEB 241989

September 1988

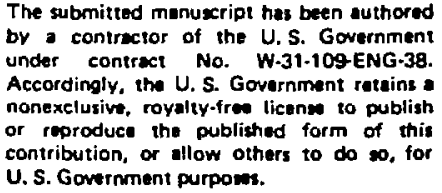

\section{DISCLAIMER}

This report was prepared as an account of work sponsored by an agency of the United States Government. Neither the United States Government nor any agency thereof, nor any of their employees, makes any warranty, express or implied, or assumes any legal liability or responsibility for the accuracy, completeness, or usefulness of any information, apparatus, product, or process disclosed, or represents that its use would not infringe privately owned rights. Reference herein to any specific commercial product, process, or service by trade name, trademark, manufacturer, or otherwise does not necessarily constitute or imply its endorsement, recommendation, or favoring by the United States Government or any agency thereof. The views and opinions of authors expressed herein do not necessarily state or reflect those of the United States Government or any agency thereof.

To be presented at the Elghth Topical Meeting on the Technology of Fusion Energy, Salt Lake City, Utah, October 9-13, 1988.

*Work supported by the U. S. Department of Energy, Office of Fusion Energy, under Contract $W-31-109-E n g-38$. 
INFLUENCE OF CARBON AND NITROGEN IMPURITIES ON THE CORROSION OF STRUCTURAL

MATERIALS IN A FLOWING-LITHIUM ENVIRONMENT

O.K. CHOPRA and A.B. HULL

Materials and Components Technology Division

Argonne National Laboratory, Argonne, IL 60439

\section{ABSTRACT}

Chemical interactions involving nonmetallic elements play a dominant role in the corrosion behavior of ferrous and vanadium base alloys in lithium. Metallographic evaluations of the surface morphology and compositional changes of lithium-exposed ferrous and vanadium alloys are presented. Data on the corrosion behavior of several ferritic, austenitic, and vanadium-based structural materials in flowing lithium are reviewed and the affects of nonmetallic elements on corrosion are discussed.

\section{INTRODUCTION}

Liquid lithium ( $\mathrm{Li}$ ) is a leading candidate as a tritium breeder material for fusion reactors because of its acceptable tritium-breeding and efficient heat transfer characteristics. The self-cooled blanket concept is particularly attractive because of the inherent simplicity of using $\mathrm{Li}$ as both a breeder and coolant. However, the compatibility of liquid $\mathrm{Li}$ with the containment materials is a major concern. Data from an investigation of the corrosion behavior of candidate structural materials in flowing $\mathrm{Li}$ loops ${ }^{1}$ indicate that mass transfer and deposition of corrosion products may determine the maximum operating temperature in some liquid-metal blanket systems.

In flowing $\mathrm{Li}$ systems, the corrosion rates of ferritic and austenitic steels reach a steady-state value after an initial transient period characterized by rapid dissolution. The steady-state corrosion rates for ferritic steels increase with an increase in temperature whereas the corrosion rates of austenitic steels are insensitive to temperature in the rarge from 370 to $550^{\circ} \mathrm{C}^{1}$ The initial dissolution stage is associated with rapid changes in surface composition and the alloy surfaces develop a dimpled appearance. The austenitic steels form a 
ferrite layer due to depletion of nickel from the steel. Both ferritic and austenitic steels show depletion of chromium (Cr). The ferritic steels show greater resistance to corrosion than the austenitic stainless stee! (SS).

The corrosion data indicate that dissolution of major alloy elements and mass transfer as well as chemical interactions between alloy elements and nonmetallic elements such as nitrogen $(\mathrm{N})$ and carbon $(\mathrm{C})$, influence the overall corrosion behavior of ferrous alloys. 1,2 An increase in the $\mathrm{N}$ content of the $\mathrm{Li}$ increases the weight losses for ferritic and austenitic steels. The formation of a ternary nitride $\mathrm{LigCrN}_{5}$ has been observed on steel specimens exposed to $\mathrm{Li}$ at temperatures between 400 and $600^{\circ}$ C.1,3-5 Mixed iron-chromium carbide $M_{23} C_{6}$ has also been detected on austenitic stainless steel exposed to C-contaminated Li. 4,5

Chemical interactions also play a dominant role in the corrosion behavior of vanadium (V) alloys. 6 Alloys containing various amounts of $\mathrm{Cr}$ and titanium (Ti) pick up $\mathrm{N}$ and $\mathrm{C}$ when exposed to $\mathrm{Li}$ that contains 20 to 50 wppm $\mathrm{N}$ and 8 to 12 wppm $\mathrm{C}$ at temperatures between 370 and $540^{\circ} \mathrm{C}$. Alloys containing 15 to $20 \% \mathrm{Ti}$ show the lowest corrosion while pure $\mathrm{V}$ exhibits the highest corrosion rate.

This paper presents data on the surface morphology and compositional changes of Liexposed ferrous and $V$ alloys. Data on the corrosion behavior of several ferritic, austenitic, and $\mathrm{V}$-based structural materials in flowing $\mathrm{Li}$ are reviewed and the effects of nonmetallic elements on corrosion are discussed.

\section{EXPERIMENTAL PROCEDURE}

Corrosion tests were conducted in a forced-circulation $\mathrm{Li}$ loop equipped with cold- and hot-trapping purification capabilities to control the concentration of nonmetallic elements. A detailed description of the loop and the test procedure has been presented previously. ${ }^{7}$ The exposure temperature and time, $\mathrm{Li}$ loop operating conditions, and the $\mathrm{N}$ content of the $\mathrm{Li}$, are given in Table 1. For all tests, $\mathrm{Li}$ was circulated at $\sim 1 \mathrm{l} / \mathrm{min}$ in the primary loop, and the concentrations of $\mathrm{C}$ and hydrogen $(H)$ in the Li were $\sim 10$ and 120 wppm, respectively.

After exposure to $\mathrm{Li}$, the specimens were cleaned in alcohol and water. Several specimens were analyzed chemically to determine the changes in the concentration of nonmetallic elements; the surface reaction products were analyzed by $x$-ray diffrartion. 
III. RESULTS

A. Ferritic and Austenitic Steels

The data for weight losses and steady-stale dissolution rates of HT-9, Fe-9Cr-1Mo, and Type 316 SS reported elsewhere 1,7,8, show that, for all alloys, an increase in the $N$ content of the $\mathrm{Li}$ from 20 to 100 wppm increases the weight loss during the initial transient period. 1

Nitrogen can react with alloy elements and $\mathrm{Li}$ to form stable ternary nitrides and thus accelerate the corrosion of ferrous alloys. 4,9 The equilibrium concentrations of $\mathrm{N}$ and $\mathrm{C}$ in $\mathrm{Li}$ for which metal nitrides and carbides are stable $5,10,11$ are shown in Fig. 1 . The ternary nitrides are soluble in alcohol or water and, therefore, are not observed on clean specimens. The presence of ternary nitride LigCrN5 on HT-9 and Type 316 SS specimens exposed during Run 6 was detected by chemical analysis of the methanol used for cleaning the specimens. ${ }^{1}$ The concentrations of the major elements (expressed as wppm in Li) that were dissolved in the methanol are given in Table 2. The high concentration of $\mathrm{Cr}$ in the solutions indicates the formation of the ternary nitride of $\mathrm{Cr}$ on the alloy surfaces exposed to $\mathrm{Li}$. $\mathrm{The} \mathrm{Cr}$ content of the methanol solution after cleaning Type 316 SS specimens was significantly greater than the $\mathrm{Cr}$ content of the methanol after cleaning HT-9 specimens. This was particularly true for specimens exposed at $482^{\circ} \mathrm{C}$. The relatively high concentrations of molybdenum (Mo) in the solutions after cleaning Type 316 SS specimens also indicate the presence of ternary nitrides involving Mo. These results indicate that chemical interactions between alloy elements and $N$ play a dominant role in the corrosion behavior of austenitic steels in $\mathrm{Li}$. The efiect of these interactions on the corrosion behavior will be larger at lower temperatures, eg., at 482 or $427^{\circ} \mathrm{C}$, because the driving force for nitride formation increases as temperature decreases.

An implication of such chemical interactions is that the corrosion behavior can not be accurately obtained from a single specimen exposed for various times; particularly for Type 316 SS. The formation of ternary nitrides during each exposure period and the subsequent loss during the cleaning procedure results in greater weight loss and corrosion rate. The relatively constant dissolution rates obtained for Type $316 \mathrm{SS}\left(\sim 2 \mathrm{mg} / \mathrm{m}^{2} . \mathrm{h}\right)$ at temperatures between 372 and $538^{\circ} \mathrm{C}$ may be attributed to chemical interactions involving $N$ and the experimental procedure. Separate specimens should be exposed to $\mathrm{Li}$ for different times to accurately establish the dissolution rates of Type 316 SS. Figure 1 indicates that the $\mathrm{N}$ 
content of the Li should be below - 1 wppm to avoid formation of ternary nitrides and their effects on corrosion.

The corrosion data from the various test runs indicate large deposits on specimen surfacəs 1.7 (for example, see Fig. 2). A detailed examination of the Li-exposed specimens reveals surface deposits on all specimens exposed at 427 or $482^{\circ} \mathrm{C}$. Specimens exposed at the downstream location contain very large particles whereas the specimens exposed at the maximum loop temperature contain fine surface deposits. Significantly fewer deposits are seen on HT-9 and Fe-9Cr-1Mo specimens than on Type 316 SS specimens. X-ray analyses indicate that these deposits are carbides and that the nature of the carbides changes with exposure time. For example, $M_{23} C_{6}$ carbides are observed after relatively short exposure times $\left(\sim 1000 \mathrm{~h}\right.$ at 427 or $482^{\circ} \mathrm{C}$ ) whereas both $M_{23} C_{6}$ and $M_{7} C_{3}$ are observed after longer exposure times ( $>2500 \mathrm{~h}$ ). The total carbon content of the specimens, however, did not increase significantly with an increase in time from 1000 to $5000 \mathrm{~h}$.

Surface deposits have also been observed on pure $\mathrm{Cr}$ specimens exposed to $\mathrm{Li}$ at 482 and $427^{\circ} \mathrm{C} .^{8}$ The deposits were identified as $\mathrm{Cr}_{23} \mathrm{C}_{6}$ for the specimen exposed at $482^{\circ} \mathrm{C}$ (maximum loop temperature) and $\mathrm{Cr}_{23} \mathrm{C}_{6}$ and $\mathrm{Cr}_{7} \mathrm{C}_{3}$ for the specimen exposed at $427^{\circ} \mathrm{C}$ (downstream location).

The ferritic and austenitic steels exposed to $\mathrm{Li}$ during Runs 4,5, and 6 were analyzed chemically to determine the changes in $C$ content. The results are plotted in Fig. 3 . Some specimens were mechanically polished to remove the surface deposits or the ferrite layer on Type 316 SS before the bulk $C$ concentration was measured. The results for Type 316 SS indicate that the material decarburizes at $538^{\circ} \mathrm{C}$ and carburizes at 482 and $427^{\circ} \mathrm{C}$; little or no change was observed at $372^{\circ} \mathrm{C}$. The influence of surface deposits is significant only for the specimens exposed at the downstream location, viz., the bulk $C$ content of these specimens is $22 \%$ lower than that of the unpolished specimen. The presence of large surface deposits on the downstream specimens is most likely due to the deposition of $\mathrm{Cr}$ from $\mathrm{Li}$. The decarburization/carburization behavior of Type 316 SS does not seem to be affected by the surface deposits. Specimens exposed at the maximum loop temperature of $482^{\circ} \mathrm{C}$ have little or no deposits but contain higher $C$ concentrations (737 wppm) than the specimens exposed at the same temperature but at the downstream location (652 wppm), which have surface deposits. The formation of ternary nitrides may, however, influence the $\mathrm{C}$ transfer. The lack of $\mathrm{C}$ transfer even after an $\sim 5000-\mathrm{h}$ exposure to $\mathrm{Li}$ at $372^{\circ} \mathrm{C}$ may be attributed to kinetic limitations and possibly the presence of ternary nitrides on the specimen surface. 
The results for HT-9 and Fe-9Cr-iMo, Fig. 3b, indicate no $C$ transfer after long exposure at temperatures between 372 and $538^{\circ} \mathrm{C}$. The slightly higher $\mathrm{C}$ content of specimens exposed at 482 and $427^{\circ} \mathrm{C}$ appears to be associated with the surface deposits.

These results indicate that chemical interactions involving $C$ are not likely to influence the overall corrosion behavior of ferrous alloys significantly. The carbides that form on the alloy surfaces are adherent. The transfer of $C$ to and from the alloys, and the carbide deposits on the surface, may, however, influence the weight change measurements. For example, a 300 wppm increase in bulk $C$ content in the foil specimens used in this investigation would correspond to an increase of $\sim 0.35 \mathrm{~g} / \mathrm{m}^{2}$ in weight. Such weight changes will be insignificant for the austenitic Type 316 SS which shows $10-1030-\mathrm{g} / \mathrm{m}^{2}$ weight loss after the initial transient weight loss period. The ferritic steels show no change in the bulk $\mathrm{C}$ content.

\section{B. Vanadium Alloys}

The corrosion data for several $\mathrm{V}$ alloys ${ }^{6}$ exposed at $482^{\circ} \mathrm{C}$ to $\mathrm{Li}$ containing $\sim 10$ wppm $C$ and 20 to 50 wppm $N$ indicate that the dissolution rates decreased in the following order: pure $V>V-3 T i-1 S i>V-5 T i-(12-15 \mathrm{Cr})>V-(10-15 \mathrm{Cr})-(3 \mathrm{Fe}-1 \mathrm{Zr})>V-(15-20 \mathrm{Ti})-7.5 \mathrm{Cr}$ All alloys picked up $\mathrm{N}$ and $\mathrm{C}$ and lost oxygen $(\mathrm{O})$. The low dissolution rates for the alloys containing $\geq 15 \% \mathrm{Ti}$ are due to the formation of a continuous surface scale. Alloys containing $<5 \mathrm{Ti} \%$ do not develop a uniform surface scale and exhibit higher corrosion rates. The addition of $\mathrm{Cr}$ to $\mathrm{V}$ seems to influence the chemical interactions and decrease the corrosion rates.

The concentrations of $\mathrm{N}$ and $\mathrm{C}$ in pure $\mathrm{V}$ and some alloys exposed to $\mathrm{Li}$ at temperatures between 427 and $538^{\circ} \mathrm{C}$ are given in Table 3. At 538, 482, and $427^{\circ} \mathrm{C}$, the solubility of $\mathrm{N}$ in pure $V$ is 4670,3570 , and 2640 wppm, respectively; that of $C$ is 487,366 , and 265 wppm, respectively. ${ }^{10}$ For pure $V$ specimens, the measured $\mathrm{N}$ content is slightly below the solubility level and the $\mathrm{C}$ content represents the saturation level. Figure 1 indicates that $V N$ is not stable at $482^{\circ} \mathrm{C}$ in $\mathrm{Li}$ containing 20 wppm $\mathrm{N}$ (conditions for Run 8). The partitioning of $\mathrm{N}$ between pure $V$ and $L i$ can be obtained from the equilibrium distribution coefficient $K_{W} 10,11$ given by

$$
K_{w}=C_{V} / C_{L}=\exp (6.52 \cdot 1394 / T)
$$


where $C_{V}$ and $C_{L}$ are the concentrations (weight units) of $N$ in $V$ and $L i$, respectively, and $\mathrm{T}$ is absolute temperature. For $20 \operatorname{wppm} \mathrm{N}$ in $\mathrm{Li}$, the equilibrium $\mathrm{N}$ content in $\mathrm{V}$ should be 2140 and 1840 wppm at 482 and $427^{\circ} \mathrm{C}$, respectively. The measured $\mathrm{N}$ concentration in pure $V$ exposed at $482^{\circ} \mathrm{C}$ is close to the equilibrium concentration. The equilibrium value is not achieved after $\sim 1400 \mathrm{~h}$ at $427^{\circ} \mathrm{C}$ due to kinetic limitations.

These results indicate that the relatively high corrosion rates for pure $\mathrm{V}$ can not be attributed to chemical interactions to form nitrides. Figure 1 shows that $\mathrm{V}_{2} \mathrm{C}$ is stable under the present exposure conditions, i.e., 10 wppm C in Li. X-ray analyses of the pure $V$ specimens, however, did not show any carbides or nitrides on the specimen surfaces. It is likely that the $\mathrm{V}_{2} \mathrm{C}$ which forms on pure $\mathrm{V}$ specimens is not adherent and spalls during $\mathrm{Li}$ exposure. This may be the dominant contribution to the weight loss of $V$ alloys.

The $V$ alloys show an increase in $N$ and $C$ content. The gain in $N$ increases with time and temperature. Analyses of the specimens with or without the surface scale indicate a significant increase in $\mathbf{N}$ content of the bulk material, a finding that is confirmed by hardness measurements which showed an increase in microhardness of the surface region of the specimens. ${ }^{6}$ However, $x$-ray analyses of these specimens did not show the formation of metal nitrides or carbides; only broadening of the $x$-ray peaks corresponding to the base material were observed. In most specimens, $\mathrm{N}$ is in solution. However, the specimens with $>1 \mathrm{wt} \% \mathrm{~N}$ were consumed in the chemical analyses and thus were not available for $x$-ray analysis.

The $\mathrm{N}$-rich scale on the $\mathrm{V}$ alloys is quite hard and brittle and can break off under thermal stresses, resulting in higher weight losses. Spalling of the surface scale was, however, rare. The corrosion mechanisms for $V$ alloys are most likely dissolution of alloy elements and chemical interactions involving $\mathrm{C}$. Chemical interactions with $\mathbf{N}$ have a secondary effect, but may be more important for the effects on mechanical properties.

\section{CONCLUSIONS}

(a) The dissolution of major alloy elements, as well as chemical interactions between $\mathrm{N}$ and $\mathrm{Cr}$ or Mo, control the corrosion behavior of ferrous alloys. The contribution of chemical interactions is significant for austenitic Type 316 SS. Thermodynamic data indicate that the N content in $\mathrm{Li}$ should be $<1$ wppm to avoid chemical interactions. 
(b) The weight loss data for Type 316 SS obtained from a single specimen exposed for various times do not accurately represent the corrosion rates. The relatively constant dissolution rates reported for Type 316 SS at temperatures between 372 and $538^{\circ} \mathrm{C}$ are most likely due to the experimental procedure and contributions of chemical interactions.

(c) When exposed to $\mathrm{Li}$ containing $\sim 10$ wppm C, the austenitic Type 316 SS decarburizes at $538^{\circ} \mathrm{C}$ and carburizes slightly at 482 and $42.7^{\circ} \mathrm{C}$. The ferritic HT-9 and Fe$9 \mathrm{Cr}-1 \mathrm{Mo}$ steels are resistant to decarburization/carburization and show little or no $\mathrm{C}$ transfer.

(d) Carbon deposits are observed on the ferritic and austenitic steel surfaces, particularly on specimens located at the downstream position. Carbon transfer does not appear to affect the dissolution behavior of ferrous alloys.

(e) The $\mathrm{V}$ alloys pick up $\mathrm{N}$ and carbon from $\mathrm{Li}$. Alloys with $\mathrm{Ti}$ or $\mathrm{Cr}$ develop a $\mathrm{N}$-rich surface layer.

(f) Chemical interactions involving $\mathrm{C}$ play an important role in the dissolution behavior of $\mathrm{V}$ alloys.

\section{ACKNOWLEDGNENTS}

This work was supported by the U.S. Department of Energy, Office of Fusion Energy, under contract No. W-31-109-Eng-38. Collette Marsh performed the carbon analyses and Urs Geiser helped with the XRD work.

\section{REFERENCES}

1. O. K. Chopra and D. L. Smith, "Influence of Temperature and Lithium Purity on Corrosion of Ferrous Alloys in A Flowing Lithium Environment," $\mathbf{L}$ Nucl. Mater, 141, 584 (1986).

2. P. F. Tortorelli, "Corrosion of Ferritic Steels by Molten Lithium: Influence of Competing Thermal Gradient Mass Transfer and Surface Product Reactions," in Proc. 3rd International Conf. on Fusion Reactor Materials, Karlsruhe, FRG, October 4-8, 1987, to be published in J. Nucl. Mater. (1988).

3. I. E. Schreinlechner and P. F. Sather, "Contribution of Minor Steel Constituents to the Behavior of Stainless Steels in Liquid Lithium," in Proc. 3rd International Conf. on Fusion Reactor Materials, Karlsruhe, FRG, October 4-8, 1987, to be published in J. Nucl. Mater. (1988). 
4. M. G. Barker and S. A. Frankham, "The Effects of Carbon and Nitrogen on the Corrosion Resistance of Type 316 Stainless Steel to Liquid Lithium," L Nucl. Mater 107218 (1982).

5. M. G. Barker, J. A. Lees, and I. E. Schreinlechner, "The Corrosion of Type 316 Stainless Steels in Static and Dynamic Liquid Lithium," in Proc. 14th Symp. on Fusion Technology, Avignon, France, September, 1986.

6. O. K. Chopra and D. L. Smith, "Corrosion Behavior of Vanadium Alloys in Flowing Lithium," in Proc. 3rd International Conf. on Fusion Reactor Materials, Karlsruhe, FRG, October 4-8, 1987, to be published in J. Nucl. Mater. (1988).

7. O. K. Chopra and D. L. Smith, "Corrosion of Ferrous Alloys in a Flowing Lithium Environment," L Nucl, Mater, 133\&134, 861 (1985).

8. O. K. Chopra and D. L. Smith, "Compatibility of Ferritic Steels in Forced Circulation Lithium and Pb-17Li Systems," in Proc. 3rd International Conf. on Fusion Reactor Materials, Karlsruhe, FRG, October 4-8, 1987, to be published in J. Nucl. Mater. (1988).

9. E. Ruedl and T. Sasaki, "Effect of Lithium on Grain-Boundary Precipitation in a Cr-Mn Austenistic Steel," ل L Nucl. Mater 116, 112 (1983).

10. D. L. Smith and K. Natesan, "Influence of Nonmetallic Impurity Elements on the Compatibility of Liquid Lithium with Potential CTR Containment Materials," Nucl. Technol. 22, 392 (1974).

11. K. Natesan, "Influence of Nonmetallic Elements on the Compatibility of Structural Materials with Liquid Atkali Metals," ل ل Nucl, Mater 115. 251 (1983). 
Table 1. Lithium Loop Operating Conditions for Various Corrosion Tests

\begin{tabular}{|c|c|c|c|c|c|c|c|}
\hline \multirow[b]{2}{*}{$\begin{array}{l}\text { Test } \\
\text { Run }\end{array}$} & \multicolumn{4}{|c|}{ Loop Temperature $\left({ }^{\circ} \mathrm{C}\right)$} & \multirow{2}{*}{$\begin{array}{l}N \text { content } \\
\text { of the } \mathrm{Li} \\
\text { (wppm) }\end{array}$} & \multicolumn{2}{|c|}{ Exposure Time $(h)$} \\
\hline & $\begin{array}{l}\text { Test } \\
\text { Vessel }\end{array}$ & $\begin{array}{l}\text { Exp. }{ }^{2} \\
\text { Vessel }\end{array}$ & $\begin{array}{l}\text { Supply } \\
\text { Vessel }\end{array}$ & $\begin{array}{l}\text { Cold } \\
\text { Trap }\end{array}$ & & $\begin{array}{l}\text { Test } \\
\text { Vessel }\end{array}$ & $\begin{array}{l}\text { Exp. } \\
\text { Vessel }\end{array}$ \\
\hline 1 & 482 & 482 & 432 & 212 & $<50$ & 1295 & 5000 \\
\hline 2 & $482^{b}$ & 482 & 407 & $230^{c}$ & $\sim 250$ & - & 1997 \\
\hline 3 & 427 & 482 & 407 & 230 & $\sim 100$ & 1100 & - \\
\hline 4 & 482 & 427 & 410 & 212 & $<100$ & 5521 & 6501 \\
\hline 5 & 427 & 372 & 372 & 206 & $\sim 100$ & 5023 & 4955 \\
\hline 6 & 538 & 482 & 410 & 208 & $\sim 50$ & 3655 & 3330 \\
\hline 8 & 482 & 427 & 426 & 213 & $\sim 20$ & 2158 & 2062 \\
\hline
\end{tabular}

a Lithium flow was from the test vessel to the specimen exposure vessel.

b Test vessel temperature changed from 482 to $427^{\circ} \mathrm{C}$ after $1540 \mathrm{~h}$.

c No flow occurred through cold trap after $890 \mathrm{~h}$ due to plugging. Plugged sections were replaced and flow started after an additional $480 \mathrm{~h}$. 
Table 2. Concentrations (wppm) of Alloy Constituents in Lithium a from Spectrochemical Analysis of Methanol Used for Cleaning Corrosion Specimens Exposed to the Lithium at 538 and $482^{\circ} \mathrm{C}$

Major Elements (ppm)

Alloy

$538^{\circ} \mathrm{C}$

$482^{\circ} \mathrm{C}$

\begin{tabular}{lrrrrrrrrr} 
& Cr & Fe & Ni & Mo & & Cr & Fe & Ni & Mo \\
\hline HT-9 & 19 & 67 & $<15$ & 10 & & 42 & 33 & $<15$ & 12 \\
Type 316 SS & 46 & 68 & 13 & 135 & & 207 & 31 & 14 & 60 \\
Lithiumb & $<5$ & 17 & 13 & $<10$ & & $<5$ & 18 & $<15$ & $<10$
\end{tabular}

a Lithium film which adheres to the specimen when it is removed from the loop

b Concentration of alloying element in the loop lithium 
Table 3. Carbon and Nitrogen Contents in Vanadium Alloys Exposed to Lithium

\begin{tabular}{|c|c|c|c|c|c|}
\hline \multirow{2}{*}{ Alloy } & \multirow{2}{*}{$\begin{array}{l}\text { Test } \\
\text { Run }\end{array}$} & \multicolumn{2}{|c|}{ Exposure Condition } & \multicolumn{2}{|c|}{ Impurity Content ${ }^{\mathrm{a}}$ (wppm) } \\
\hline & & Temp $\left({ }^{\circ} \mathrm{C}\right)$ & Time $(h)$ & Carbon & Nitrogen \\
\hline \multirow[t]{4}{*}{ Pure V } & \multicolumn{3}{|c|}{ Unexposed } & 360 & $161 \pm 41$ \\
\hline & 8 & 482 & 484 & $340(330)$ & $681 \pm 65$ \\
\hline & 8 & 482 & 1508 & 270 & $3404 \pm 187(3410 \pm 129)$ \\
\hline & 8 & 427 & 1405 & 320 & $565 \pm 71$ \\
\hline \multirow[t]{4}{*}{$V-10 \mathrm{Cr}-3 \mathrm{Fe}-\mathrm{Zr}$} & \multicolumn{3}{|c|}{ Unexposed } & 890 & $271 \pm 66$ \\
\hline & 6 & 538 & 590 & 1190 & $12418 \perp 621(6258 \pm 227)$ \\
\hline & 8 & 482 & 1080 & 1070 & + \\
\hline & 6 & 482 & 687 & 990 & $4570 \pm 250$ \\
\hline \multirow[t]{4}{*}{$V-15 \mathrm{Cr}-5 \mathrm{Ti}^{\mathrm{b}}$} & \multicolumn{3}{|c|}{ Unexposed } & 390 & $527 \pm 109$ \\
\hline & 6 & 482 & 619 & 530 & \\
\hline & 8 & 482 & 1992 & 570 & $2361 \pm 114(1955 \pm 78)$ \\
\hline & 8 & 427 & 1405 & 500 & $607 \pm 84$ \\
\hline \multirow[t]{4}{*}{$V-15 \mathrm{Cr}-5 \mathrm{TiC}$} & \multicolumn{3}{|c|}{ Unexposed } & 390 & $299 \pm 68$ \\
\hline & 6 & 538 & 794 & & $(4895 \pm 179)$ \\
\hline & 6 & 538 & 1384 & $(\overrightarrow{670)}$ & $11935 \pm 434(10022 \pm 505)$ \\
\hline & 6 & 482 & 1618 & 700 & $2808 \pm 177$ \\
\hline \multirow[t]{4}{*}{$V-20 T i$} & \multicolumn{3}{|c|}{ Unexposed } & - & $566 \pm 168$ \\
\hline & 6 & 538 & 1384 & $\ldots$ & $8862 \pm 328(5735 \pm 295)$ \\
\hline & 6 & 482 & 619 & - & $604 \pm 124$ \\
\hline & 6 & 482 & 1618 & - & $(2595 \pm 110)$ \\
\hline
\end{tabular}

a Values within brackets represent concentrations for specimens which were mechanically polished to remove the surface reaction products.

b Cam heat

C ANL heat 
VIII. FIGURE CAPTIONS

Figure 1. Equilibrium Values of Nitrogen and Carbon Concentration in Lithium for which Metal Nitrides and Carbides are Stable

Figure 2. Examples of Surface Deposits on HT-9 and Type 316 SS

Figure 3. Effect of Lithium Exposure on Carbon Concentration in (a) Austenitic and (b) Ferritic Steels 


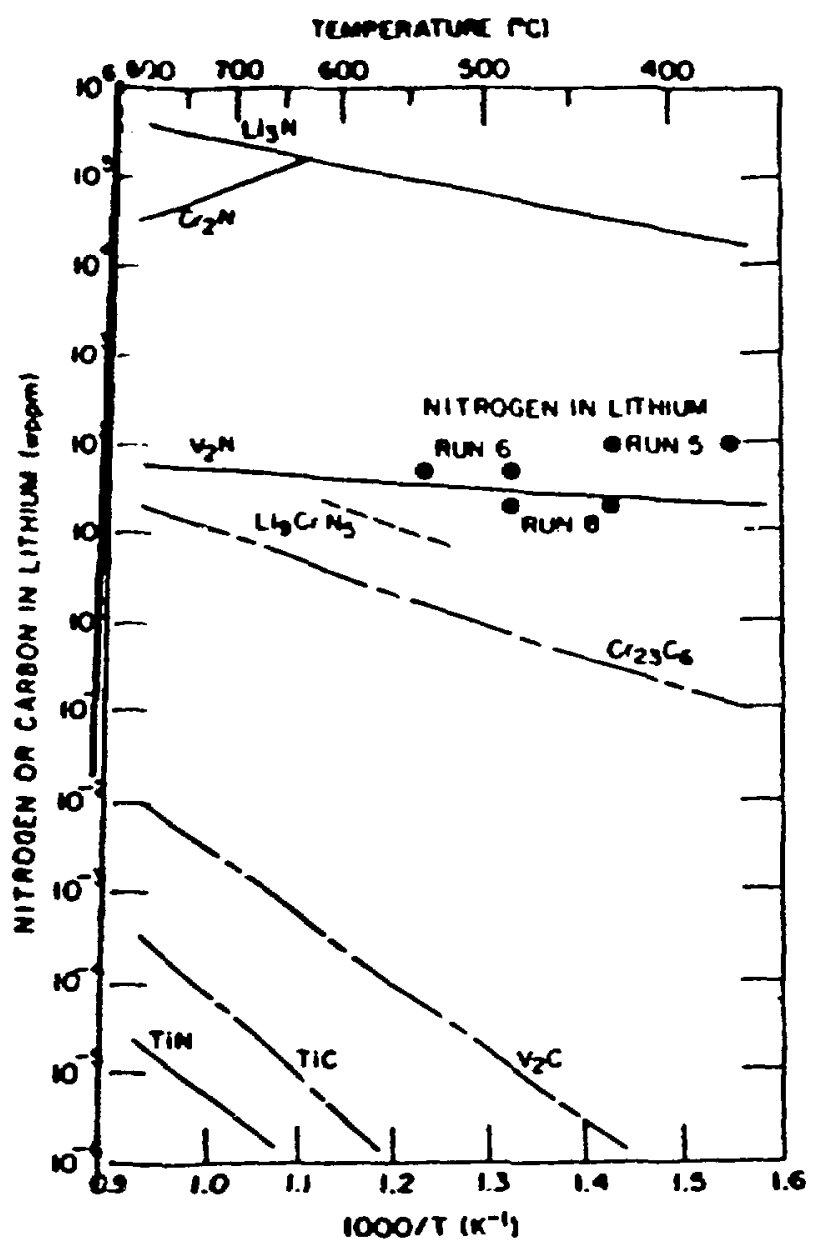

Fich 

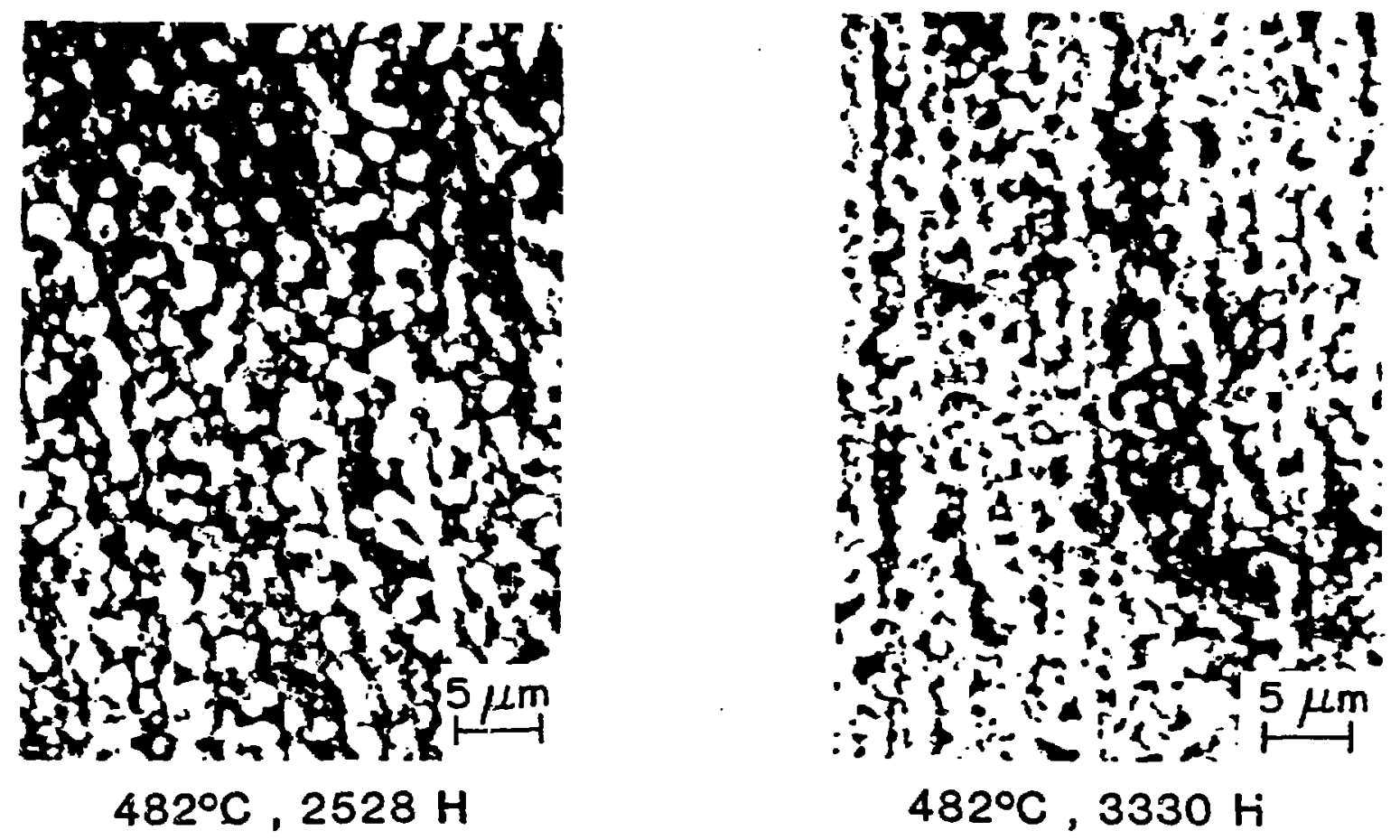
TEMPERATURE $\left({ }^{\circ} \mathrm{C}\right)$

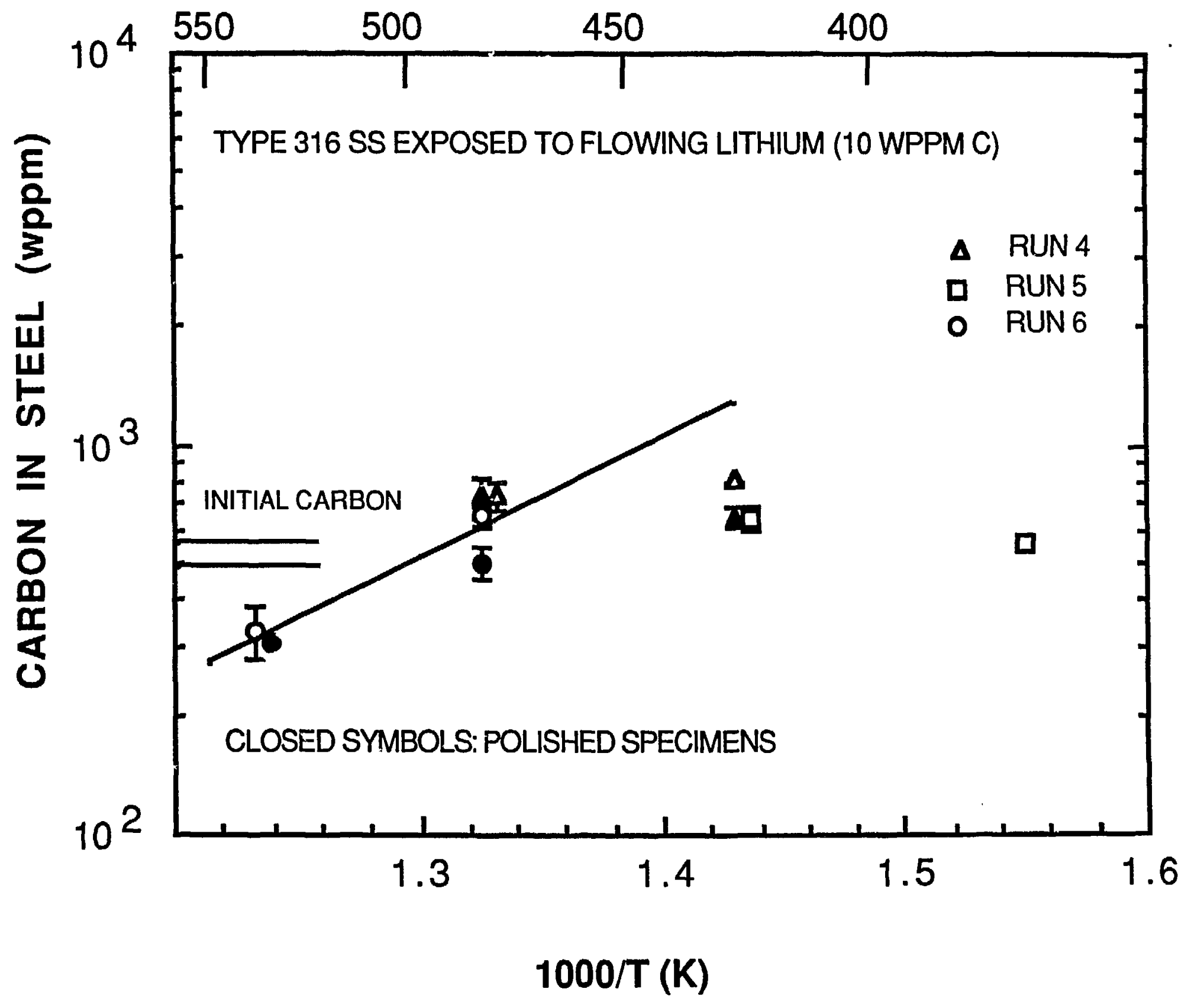

